\title{
Factors Influencing iPad Acceptance in Mandatory Conditions by Students: Cross-Classes Analysis
}

Faktor-Faktor yang Mempengaruhi Penerimaan iPad pada Kondisi Wajib Pakai oleh Mahasiswa: Analisis Lintas Angkatan

Received:

8 June 2020

Accepted:

29 June 2020

Published:

19 August 2020
1*Samiaji Sarosa, ${ }^{2}$ Agustina Retno Setyowati

${ }^{1}$ Program Studi Akuntansi, Universitas Atma Jaya Yogyakarta,

${ }^{2} P T$ Coca Cola Amatil Indonesia

${ }^{1,2}$ Indonesia

E-mail: ${ }^{1}$ samiaji.sarosa@uajy.ac.id, agustina.setyowati@ccamatil.com

*Corresponding Author

\begin{abstract}
This article is investigating the acceptance of the iPad among new students at a university. IPad usage is compulsory, and the purchase is part of the new student admission package. Two previous surveys using UTAUT have shown mixed results. The author decided to use survey results from both studies and reanalyze the questionnaire's answers. Data analysis was conducted using the SEM-PLS tool. The result showed only Anxiety and Self-Efficacy influencing Intention to Use while Intention to Use and Facilitating Condition influencing the use of iPad. The relation between Self-Efficacy and Intention to Use was moderated by gender, while the relationship between Intention to Use and Usage was moderated by experience in using a tablet.
\end{abstract}

Keyword-Compulsory Usage, UTAUT, iPad, New Students

Abstrak-Artikel ini meneliti penerimaan iPad di kalangan mahasiswa baru di sebuah universitas. Penggunaan iPad tersebut bersifat wajib dan pembeliannya adalah bagian dari paket penerimaan siswa baru. Dua survei sebelumnya menggunakan UTAUT telah menunjukkan hasil yang berbeda. Penulis memutuskan untuk menggunakan data gabungan dari hasil kedua survei pada penelitian terdahulu dan menganalisis kembali jawaban kuesioner. Analisis data dilakukan dengan menggunakan alat SEM-PLS. Hasil yang didapatkan adalah hanya Kecemasan dan Self-Efficacy yang memengaruhi Niat Penggunaan sementara Niat Penggunaan dan Kondisi Memfasilitasi memengaruhi Penggunaan iPad. Hubungan antara Self-Efficacy dan Niat Penggunaan dimoderatori oleh Gender sementara hubungan antara Niat Penggunaan dan Penggunaan dimoderasi oleh Pengalaman dalam menggunakan tablet.

Kata Kunci-Pemakaian Wajib, UTAUT, iPad, Mahasiswa Baru 
INTENSIF, Vol.4 No.2 August 2020

ISSN: 2580-409X (Print) / 2549-6824 (Online)

DOI: https://doi.org/10.29407/intensif.v4i2.14455

\section{INTRODUCTION}

Since the academic year 2000/2001, the Faculty of Business and Economics, Atma Jaya University Yogyakarta (FBE UAJY), requires new students to buy international textbooks in English. Five mandatory textbooks must be purchased as part of the entrance fee. The five books are for Introductory Accounting, Introductory Business, Economics, and Business Mathematics, Introductory Information Systems, and Introductory Microeconomics. Since the 2015/2016 academic year, FBE UAJY has changed mandatory textbooks from printed forms to electronic format (ebook). With the change in format, new FBE UAJY students are required to buy an iPad as a tool for reading mandatory textbooks in the form of the ebook. The policy was greeted with a variety of reactions, some were supportive, and some were not. In or to get a complete picture of the obligation to use the iPad, several studies have been conducted. FBE UAJY der students iPad users were surveyed using the DeLone and McLean framework [1][2] conducted by Kelvin[3]. The result can be said that the obligation to use the iPad is considered auspicious.

Then two surveys were carried out to several FBE UAJY iPad users using the Unified Theory of Acceptance and Use of Technology (UTAUT) framework [4] [5]. The first survey was conducted on 349 students in 2015 and 2016 [6][7] showed that the intention to use iPad among FBE UAJY students was influenced by anxiety, attitudes toward use, business expectations, and self-efficacy with R2 of 39,6\%. Variable Conditions that Facilitate along with the intention of use affect the use of iPad with R2 of 36,9\% [6][7]. The moderating variable Age, Gender, and Experience [4][5] did not affect FBE UAJY students in using iPad [6] [7]. The second survey [8] still uses UTAUT [4][5] but adds the Apple iPad brand reputation variable [9] and the Pleasure Perception using the iPad [10]. The second survey was distributed to all 2016 FBE UAJY students totaling 706 people with the results of 589 returned and could be used. This survey results indicate that Intention to Use iPad by FBE UAJY students is influenced by Attitudes Towards Usage, Business Expectations, Facilitating Conditions, Performance Expectations, and Self Efficacy with R2 of 34.88\% [8]. Variable Conditions that Facilitate Together with the intention of use affect the use of iPad with R2 of 27.93\% [8]. The moderating variable Age, Gender, and Experience [4], [5] did not affect FBE UAJY students in using the iPad [8]. The survey results showed that there were differences between the 2015-2016 army groups and the 2018 class, namely the Anxiety and Hope Performance variable. Besides, R2 for all surveys is below $40 \%$, which means various research variables can only explain the phenomenon of intention to use and use under $40 \%$ [11].

The inconsistency of the results of the two surveys and the low R2 raises the question of what affects the acceptance of the iPad in new students of FBE UAJY. This article seeks to find 
answers to these problems by reviewing and reanalyzing the results of the two previous surveys. It is hoped that these factors can be found that affect the reception of the iPad.

The author then tries to combine data from the two surveys to see if the analysis with UTAUT will give different results. The UTAUT used was the 2003 version [5] using the Attitude Towards Usage, Self Efficacy, and Anxiety variables that were not included in the final model as in surveys 1 and 2 [6]-[8]. Further explanation will be given in the next section.

\section{RESEARCH METHOD}

UTAUT has been used extensively in various studies. UTAUT was first formulated by Venkatesh, V, M.G. Morris, G.B. Davis, and F.D. Davis. In 2003 [5]. UTAUT has been tested and used in various studies regarding the acceptance of new or considered new technologies. For example, UTAUT is used in researching technology acceptance in the scope of hospitals and health care [12][13], in researching technology acceptance in the scope of education [14][15], in researching technology acceptance in the scope of the banking and financial industries [16][17], and many others.

The UTAUT model used in this article is a model that was published in 2003 using additional variables Attitudes Towards Use, Self Efficacy, and Anxiety [5][14]. In the final UTAUT model, Venkatesh et al. do not include Attitudes Towards Use, Self Efficacy, and Anxiety because the results of statistical tests do not show significant results [5]. However, in the previous author's research, it was found that the Attitude Towards Use and Self Efficacy influenced the Intention of Use [6]-[8] in the results of the second survey. In contrast, anxiety only proved to affect the first survey [6] [7]. The UTAU model used can be seen in Figure 1 below.

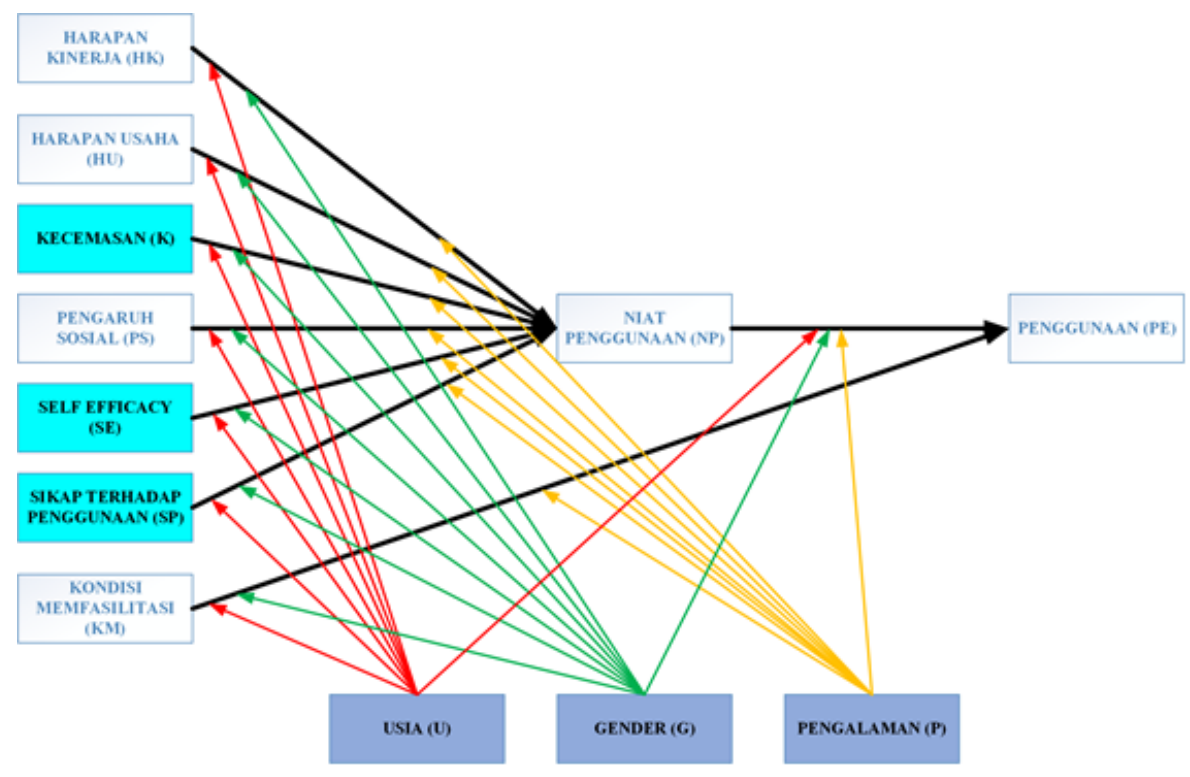

Figure 1. UTAUT Model [5], [14] 
INTENSIF, Vol.4 No.2 August 2020

ISSN: 2580-409X (Print) / 2549-6824 (Online)

DOI: https://doi.org/10.29407/intensif.v4i2.14455

In this paper, the author tries to re-examine all relations between the moderating variables Age, Gender, and Experience on all the relations of other variables. The author also includes the Attitude Towards Usage, Self Efficacy, and Anxiety variables found in the 2003 UTAUT model [5][14] following the suggestions of Venkatesh, Thong, and Xu [4]. An explanation of the variables and hypothesis development will be presented in the next section.

Performance Expectation (Harapan Kinerja/ HK) is the perception of the extent to which students believe that their performance in academia and lectures will improve using certain technologies [4][5]. In this study, HK is measured by students' perceptions of how the iPad will help them in their academic activities, do their assignments in a shorter time, increase productivity, and have better grades [14][15]. In addition, iPad usage will be moderated by Age, Gender, and Experience [4][14]. The experience in this study is based on whether students have used a tablet computer before. Business Expectation (Harapan Usaha/ HU) is the perception of the level of effort required by students to use iPad in order to support their academic activities [15][14][4]. Social Influence (PS) is the level of students' perceptions of how fellow students, lecturers, and others view how students should use their iPad [5][14], [18]. PS is a subjective norm that might influence the intention to use a technology [19]. Facilitating Conditions (kondisi memfasilitasi/KM) is the level of perception a student believes that supporting infrastructure exists to help them use the system [5]. In this study, KM is measured by examining the availability of resources to support students in using iPad, iPad compatibility with other devices owned by students, student knowledge to use iPad, and after-sales support provided by faculty and vendors [14]. KM in UTAUT will affect the Use (Pengguna/ PE) while HU, HK, and PS will affect the Intention of Use (Nilai Pengguna/ NP) [12][4][20].

Attitudes Towards Usage, Self Efficacy, and Anxiety were found in the initial UTAUT model. However, they then were not used because the results of statistical tests were not proven to affect NP significantly. Nevertheless, in the previous two surveys conducted by the author, it was proven that there was a significant influence [6]-[8]. Attitude Towards Use (Sikap Terhadap Pengguna/ SP) is a positive or negative attitude towards students using iPad [5]. SP is derived from the Theory of Reasoned Action [21][22]. Self Efficacy (SE) is an assessment of a person's ability to use technology such as an iPad to complete a particular job or task [5][14] [23][24]. Anxiety (K) or Computer Anxiety is a measurement of whether someone using technology will cause anxious or emotional reactions [5][14][10] [24] [25].

There are four moderating variables in UTAUT namely Gender $(\mathrm{G})$, Age (Usia/ U), Experience (Pengalaman/ P), and Voluntary use of technology [4][5][14]. In this article, volunteerism will be ignored because the use of the iPad is mandatory for all respondents [6][8]. The author wants to test whether this moderating variable will be a moderator in the 
relationship between variables that affect NP (HK, HU, K, PS, SE, and SP) as well as the relationship between PE variables (NP and KM).

Based on all the descriptions above, several hypotheses will be tested for this study as follows:

- H1 HK will affect NP. G, U, and P will moderate h1b, the effect of HK on NP.

- H2 HU will affect NP. G, U, and P will moderate the h2b effect of HU on NP.

- H3 K will affect NP. H3b, the effect of $\mathrm{K}$ on NP, will be moderated by G, $\mathrm{U}$, and P.

- H4 PS will affect NP. G, U, and P will moderate h4b PS influence on NP.

- H5 SE will affect NP. H5b, the effect of SE on NP, will be moderated by G, U, and P.

- H6 NP will affect PE. H6b, the effect of NP on PE, will be moderated by G, U, and P.

- $\mathrm{H} 7 \mathrm{KM}$ will affect PE. H7b, the influence of KM on PE, will be moderated by G, U, and P.

The survey was developed using a questionnaire created by Venkatesh et al. [4][5] and modified to suit the FBE UAJY students' context. The survey was distributed to students of 2015, 2016, and 2018 FBE UAJY [6]-[8]. The total population of FBE UAJY students in these three classes is 2016 students. The sampling process was done purposively [26] [27]. The survey is distributed electronically or in print through lecturers of courses taken simultaneously by new students as a package. It minimizes students filling more than once and is expected to be able to reach all batches of students who are the target of research. It is expected that with this strategy, the selection of respondent students represents the three forces [26][27]. A total of 938 questionnaires were returned and filled in completely, giving a response rate of $46.52 \%$.

For data analysis, Structural Equation Modeling or SEM is used. SEM used is Partial Least Square or SEM PLS[28] [29]. For analysis using SEM, SmartPLS software version 3 is used [30]. Analysis using SmartPLS version 3 begins by examining the Outer Model[28]-[30]. The Outer Model output of SmartPLS is used to evaluate Convergent Validity, Discriminant Validity, Composite Reliability, Average Variance Extracted (AVE), and Cronbach's Alpha. As a guide, the value of Convergence Validity must be greater than 0.7, AVE is more significant than 0.5, and Cronbach Alpha must be greater than 0.6 [31]. Therefore, we decided to delete all indicators and variables with an Outer Loading of 0.7, including the SP variable. All variables except SP show Cronbach Alpha more significant than 0.6. Thus, the research model is valid and reliable [26][27]. The results of data processing will be discussed in section III. 
INTENSIF, Vol.4 No.2 August 2020

ISSN: 2580-409X (Print) / 2549-6824 (Online)

DOI: https://doi.org/10.29407/intensif.v4i2.14455

\begin{tabular}{llll}
\hline \hline Table & \multicolumn{3}{c}{ Table Column Head } \\
\cline { 2 - 3 } Head & Table column subhead & Subhead & Subhead \\
\hline copy & \multicolumn{2}{c}{ More table copy } \\
\hline
\end{tabular}

\section{RESULT AND DISCUSSION}

The survey results obtained some data that shows the respondents' overall profile by gender, study program, age, and experience using a tablet. A summary of the data is presented in table 1 below.

Table 1. PROFILE OF RESPONDENTS

\begin{tabular}{llll}
\hline \hline & & Total & Proportion \\
\hline Gender & Male & 378 & $40,2 \%$ \\
\hline Never used a tablet before & Wanita & 560 & $59,8 \%$ \\
\hline & Yes & 371 & $39,55 \%$ \\
\hline No & 552 & $58,84 \%$ \\
\hline Study program & No Answering & 15 & $1,61 \%$ \\
\hline & Accounting & 414 & $44,13 \%$ \\
\hline & Management & 371 & $39,55 \%$ \\
\hline & Economy & 67 & $7,14 \%$ \\
\hline & No Answering & 86 & $9,18 \%$ \\
\hline
\end{tabular}

For the hypothesis test, the Bootstrapping method is used on SmartPLS version 3.0 with a two-tailed test and a confidence level of $95 \%[30]$. A hypothesis will be accepted if the Original Sample value is in line with the hypothesis, and the T Statistical value is higher than 1.96 (twotailed test), and the P-value is less than 0.05 [28]-[30]. Hypothesis test results can be seen in Table 2 below.

Table 2. HYPOTHESIS TEST RESULTS

\begin{tabular}{|c|c|c|c|c|c|}
\hline & $\begin{array}{l}\text { Original } \\
\text { Sample }\end{array}$ & $\begin{array}{c}\text { Sample } \\
\text { Mean }\end{array}$ & $\begin{array}{l}\text { Standard } \\
\text { Deviation }\end{array}$ & T Statistics & P Values \\
\hline HK -> NP & -0.055 & -0.049 & 0.051 & 1.064 & 0.288 \\
\hline HU $>>$ NP & 0.058 & 0.053 & 0.037 & 1.576 & 0.115 \\
\hline$K$-> NP & -0.323 & -0.322 & 0.032 & 10.187 & 0.000 \\
\hline PS -> NP & 0.054 & 0.052 & 0.036 & 1.506 & 0.132 \\
\hline$S E->N P$ & 0.267 & 0.264 & 0.035 & 7.578 & 0.000 \\
\hline KM -> PE & 0.074 & 0.072 & 0.023 & 3.256 & 0.001 \\
\hline NP -> PE & 0.772 & 0.776 & 0.018 & 43.314 & 0.000 \\
\hline U x HK -> NP & 0.006 & -0.007 & 0.108 & 0.054 & 0.957 \\
\hline U $x$ HU $->$ NP & 0.016 & 0.015 & 0.068 & 0.240 & 0.810 \\
\hline U x PS -> NP & -0.050 & -0.038 & 0.074 & 0.679 & 0.497 \\
\hline U x SE -> NP & -0.026 & -0.030 & 0.062 & 0.421 & 0.674 \\
\hline
\end{tabular}


INTENSIF, Vol.4 No.2 August 2020

ISSN: 2580-409X (Print) / 2549-6824 (Online)

DOI: https://doi.org/10.29407/intensif.v4i2.14455

Table 2. HyPOTHESIS TEST RESULTS [CONTINUE]

\begin{tabular}{|c|c|c|c|c|c|}
\hline & $\begin{array}{l}\text { Original } \\
\text { Sample }\end{array}$ & $\begin{array}{c}\text { Sample } \\
\text { Mean }\end{array}$ & $\begin{array}{l}\text { Standard } \\
\text { Deviation }\end{array}$ & T Statistics & P Values \\
\hline U x K -> NP & -0.026 & -0.016 & 0.071 & 0.369 & 0.712 \\
\hline G $x$ HK -> NP & -0.010 & -0.007 & 0.038 & 0.264 & 0.792 \\
\hline G x HU $->$ NP & 0.019 & 0.021 & 0.036 & 0.529 & 0.597 \\
\hline G x PS -> NP & -0.013 & -0.014 & 0.044 & 0.297 & 0.766 \\
\hline G $\times$ SE -> NP & 0.081 & 0.082 & 0.033 & 2.451 & 0.014 \\
\hline Gx K -> NP & 0.046 & 0.041 & 0.033 & 1.392 & 0.164 \\
\hline$P \times H K ~->~ N P$ & -0.041 & -0.036 & 0.041 & 1.003 & 0.316 \\
\hline$P \times H U ~->N P$ & 0.049 & 0.042 & 0.038 & 1.301 & 0.194 \\
\hline$P \times P S->N P$ & -0.015 & -0.014 & 0.038 & 0.379 & 0.704 \\
\hline P $\times$ SE -> NP & -0.030 & -0.031 & 0.034 & 0.867 & 0.386 \\
\hline$P \times K ~->N P$ & 0.027 & 0.028 & 0.032 & 0.864 & 0.388 \\
\hline U X KM -> PE & 0.078 & 0.077 & 0.062 & 1.266 & 0.206 \\
\hline U x NP -> PE & -0.005 & -0.006 & 0.061 & 0.081 & 0.935 \\
\hline G X KM -> PE & -0.024 & -0.021 & 0.023 & 1.040 & 0.299 \\
\hline G x NP $\rightarrow$ PE & 0.003 & 0.001 & 0.022 & 0.139 & 0.890 \\
\hline$P \times K M ~->P E$ & 0.049 & 0.047 & 0.023 & 2.117 & 0.035 \\
\hline$P \times N P$-> PE & -0.027 & -0.025 & 0.021 & 1.282 & 0.200 \\
\hline
\end{tabular}

From the results of the hypothesis test in table 2, it can be seen that the accepted hypothesis is:

- $\mathrm{H} 3 \mathrm{~K}$ will affect NP.

- H5 SE will affect NP. The effect of SE on NP will be moderated by G only.

- H6 NP will affect PE.

- H7 KM will affect PE. Palone will moderate the effect of KM on PE.

Performance Expectations do not affect the Intention to Use [4][5] because at the time of this survey, students had been using the iPad for a while, and it turned out that it did not affect their academic achievement. Based on student observations and interviews using the iPad to access lecture material and doing some assignments designed to be done with a tablet. Nevertheless, there are also many tasks, extraordinarily complex calculations, or the preparation of papers that cannot be done comfortably with the iPad. Students generally need conventional computers for this purpose.

Business Expectations do not affect the Intention to Use because most students already have a smartphone before. The operation of a smartphone is not much different from the operation of a tablet. Thus students do not need more effort to use iPad [4][5]. It is also supported by the fact that almost $40 \%$ of students have used tablets before.

Social Influence does not affect the Intention of Use [4][5]t because the use of the iPad is mandatory for new students of FBE UAJY. This obligation seems to reduce the influence of 
INTENSIF, Vol.4 No.2 August 2020

ISSN: 2580-409X (Print) / 2549-6824 (Online)

DOI: https://doi.org/10.29407/intensif.v4i2.14455

other people's views on the use of the iPad. There were several expressions captured during the interview that generally FBE UAJY lecturers did not like using the iPad as a means of entertainment, especially games. Many students use their iPad to play games, even in class during class.

The findings regarding moderation variables are quite impressive. Gender moderates the relationship between Self-Efficacy and Intention of Use [5] [14] [23] [24]. It was found that male students had a low self-efficacy of 3,296, which was higher than the average of female students of 3,271. The mode for all respondents is the same, which is three, but in the male students, the fourth question item for Self-Efficacy is four while the female student is 3 . It is in line with previous research [32].

The second moderation variable that gives effect is experience. Experience moderates the relationship between facilitating conditions and use [5], [14]. The experience of using tablets and smartphones that are similar in operation to tablets strengthens the relationship between Facilitating Conditions and Use. It is in line with previous studies [33] [34] [35]. For R2 in this study can be seen in the following Table 3 .

Table 3. $R^{2}$ RESULT

\begin{tabular}{lrr}
\hline \hline & R Square & \multicolumn{1}{c}{ R Square Adjusted } \\
\hline NP & 0.228 & 0.208 \\
\hline PE & 0.625 & 0.621 \\
\hline
\end{tabular}

It can be seen that R2 here for PE is $62.5 \%$. This result is higher than the two previous studies, which were just under $40 \%$. Table 4 presents a comparison of the results of the studies of the three surveys that have been carried out.

Table 3. COMPARISON OF STUDY RESULTS

\begin{tabular}{llll}
\hline \hline & Survey $\mathbf{1}$ & Survey $\mathbf{2}$ & Survey $\mathbf{3}$ \\
\hline Anxiety -> Intention to Use & Take effect & No effect & Take effect \\
\hline Attitudes toward Use -> Intention of Use & Take effect & Take effect & Deleted \\
\hline Business Expectations -> Intention to Use & Take effect & Take effect & No effect \\
\hline Facilitating Conditions -> Use & Take effect & Take effect & Take effect \\
\hline Intention of Use -> Use & Take effect & Take effect & Take effect \\
\hline Performance Expectations -> Intention to Use & No effect & Take effect & No effect \\
\hline Self-Efficacy -> Intention of Use & Take effect & Take effect & Take effect \\
\hline Social Influences -> Intention of Use & No effect & No effect & No effect \\
\hline
\end{tabular}

Attitudes towards usage turned out to have to be aborted at the reliability validity test stage so that it could be considered not to affect Intention of Use [5] [21]. In the current generation, the 
use of devices in everyday life is a necessity, so it was never thought of as an intention. The Anxiety variable was found to be influential in studies 1 and 3 but did not affect study 2 [6]-[8]. Anxiety about using an iPad might be influenced by the fact that more than $50 \%$ have never used a tablet before, let alone an iPad with a reputation as a top gadget. Business Expectations in studies 1 and 2 effects but do not affect study 3 . it may be influenced by the operation of modern devices similar to each other. The similarity of smartphones and tablets is suspected of making the Harapan Usaha no significant effect. Likewise, Performance Expectations that do not affect.

Overall, the results of the combined analysis of data from surveys covering 2015, 2016, and 2018 batches [6]-[8] obtained results that were the "conclusions" of the two previous surveys. The final UTAUT model, according to the results of the hypothesis test, can be seen in Figure 2 below.

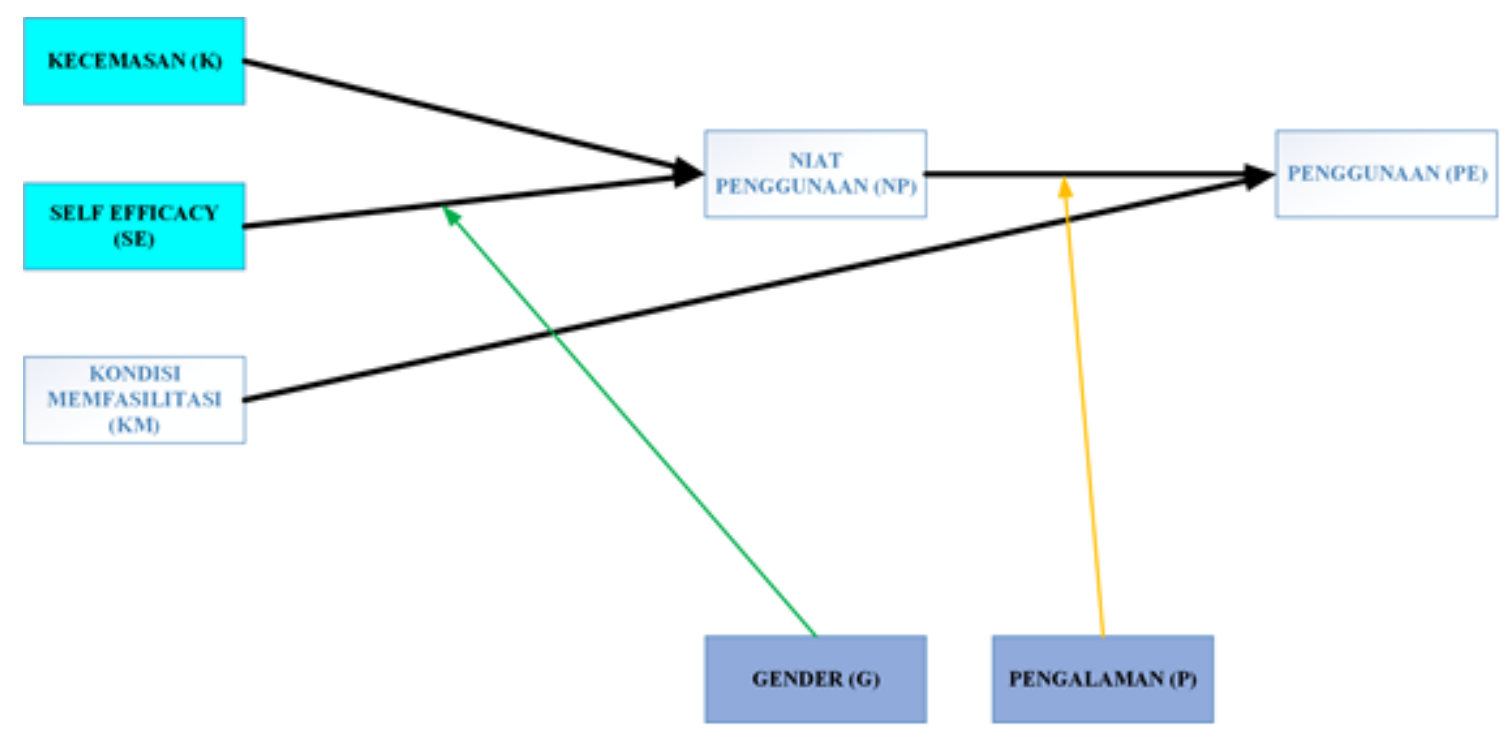

Figure 2. Final Results Of The Utaut Model

\section{CONCLUSION}

From the results of the data re-processing of two surveys on the obligation to use iPad on FBE UAJY students class of 2015,2016, and 2018, several conclusions can be formulated. First, the use of iPad by students of 2015, 2016, and 2018 FBE UAJY is influenced by the Intention of Use and Facilitating Conditions in line with previous studies. The intention of use is influenced by Anxiety, Self-Efficacy, and Facilitating Conditions. Gender moderates the relationship between Self-Efficacy and Intentions of Use while experience moderates the relationship between Facilitating Conditions with Use. Performance Expectations, Business Expectations, and Social Influence have been proven not to affect intention to use. Attitudes towards Usage variables did not even pass the validity and reliability test to be included in this study. 
INTENSIF, Vol.4 No.2 August 2020

ISSN: 2580-409X (Print) / 2549-6824 (Online)

DOI: https://doi.org/10.29407/intensif.v4i2.14455

This study has several limitations, including a higher proportion of respondents in the class of 2018 students. However, different results from previous surveys convinced the author that these limitations did not have a significant impact. The second limitation is the exclusion of students from the 2017 class, due to operational constraints at the time of the survey, which was beyond the author's control. The third is the reliability of the UTAUT device itself. UTAUT is more than 17 years old since it was published in 2003. In the second survey, the authors have tried to include other variables but have not given encouraging results seen in R2, which is below $40 \%$. The author believes it is necessary to look for other, more appropriate tools to examine the phenomenon of compulsory technology acceptance.

\section{REFERENCES}

[1] W. H. DeLone and E. R. McLean, "The DeLone and McLean model of information systems success: A ten-year update," J. Manag. Inf. Syst., vol. 19, no. 4, pp. 9-30, 2003, doi: 10.1080/07421222.2003.11045748.

[2] Y. S. Wang and Y. W. Liao, "Assessing eGovernment systems success: A validation of the DeLone and McLean model of information systems success," Gov. Inf. Q., vol. 25, no. 4, pp. 717-733, 2008, doi: 10.1016/j.giq.2007.06.002.

[3] K. E. Pramudita, "Penilaian Kesuksesan Penerapan Apple iPad Mini Menggunakan Model DeLone and McLEan 2003 pada Fakultas Ekonomi Universitas Atma Jaya Yogyakarta," Atma Jaya Yogyakarta University, Yogyakarta, 2017.

[4] V. Venkatesh, J. Y. L. Thong, and X. Xu, "Unified theory of acceptance and use of technology: A synthesis and the road ahead," J. Assoc. Inf. Syst., vol. 17, no. 5, pp. 328 376, 2016, doi: 10.17705/1 jais.00428.

[5] V. Venkatesh, M. G. Morris, G. B. Davis, and F. D. Davis, "User acceptance of information technology: Toward a unified view," MIS Q. Manag. Inf. Syst., vol. 27, no. 3, pp. 425-478, 2003, doi: 10.2307/30036540.

[6] Penulis, 2017,

[7] Penulis Artikel 12019

[8] Penulis, Artikel 22019,

[9] A. Morgan-Thomas and C. Veloutsou, "Beyond technology acceptance: Brand relationships and online brand experience," J. Bus. Res., vol. 66, no. 1, pp. 21-27, 2013, doi: 10.1016/j.jbusres.2011.07.019.

[10] V. Venkatesh, "Determinants of Perceived Ease of Use: Integrating Control, Intrinsic Motivation, and Emotion into the Technology Acceptance Model," Inf. Syst. Res., vol. 11, no. 4, pp. 342-365, 2000, doi: 10.1287/isre.11.4.342.11872.

[11] D. N. Gujarati, Basic Econometrics, 4th ed. Boston: McGraw-Hill, 2003.

[12] R. Sharifian, F. Askarian, M. Nematolahi, and P. Farhadi, "Factors influencing nurses' acceptance of hospital information systems in Iran: application of the Unified Theory of Acceptance and Use of Technology," Heal. Inf. Manag. J. vol. 43, no. 3, pp. 23-28, 2014, doi: 10.12826/18333575.2014.0001.Sharifian.

[13] A. Kohnke, M. L. Cole, and R. Bush, "Incorporating UTAUT predictors for understanding home care patients' and clinician's acceptance of healthcare telemedicine equipment," J. Technol. Manag. Innov., vol. 9, no. 2, pp. 29-41, 2014, doi: 10.4067/S0718-27242014000200003.

[14] F. Akbar, "What affects students' acceptance and use of technology? A test of UTAUT in the context of a higher-education institution in Qatar," Carnegie Mellon University, USA, 2013. 
[15] J. Marchewka, C. Liu, and K. Kostiwa, "An Application of the UTAUT Model for Understanding Student Perceptions Using Course Management Software," Commun. IIMA, vol. 7, no. 2, p. 93, 2007.

[16] D. T. Morales and F. L. Trinidad, "Digital Mortgage Banking Acceptability in Philippine Universal Banks: Evidence From Utaut Model,” J. Inf. Syst. Technol. Manag., vol. 4, no. 15, pp. 01-15, 2019, doi: 10.35631/jistm.415001.

[17] J. Khalilzadeh, A. B. Ozturk, and A. Bilgihan, "Security-related factors in extended UTAUT model for NFC based mobile payment in the restaurant industry," Comput. Human Behav., vol. 70, pp. 460-474, 2017, doi: 10.1016/j.chb.2017.01.001.

[18] L. L. Brennan and V. E. Johnson, "Learning Technology While Teaching Technology Management: A Trial of Distance Learning in Higher Education," in Organizational Achievement and Failure in Information Technology Management, M. Khosrowpour, Ed. Hershey: IDEA Group Publishing, 2000, pp. 39-60.

[19] E. Tan and J. Leby Lau, "Behavioural intention to adopt mobile banking among the millennial generation," Young Consum., vol. 17, no. 1, pp. 18-31, 2016, doi: 10.1108/YC-07-2015-00537.

[20] A. A. Taiwo, and A. G. Downe, "The theory of user acceptance and use of technology (UTAUT): A meta-analytic review of empirical findings," J. Theor. Appl. Inf. Technol., vol. 49, no. 1, pp. 48-58, 2013.

[21] I. Ajzen and M. Fishbein, Understanding attitudes and predicting social behavior. Englewood Cliffs, NJ: Prentice-Hall, 1980.

[22] R. J. Hill, M. Fishbein, and I. Ajzen, Belief, Attitude, Intention, and Behavior: An Introduction to Theory and Research., vol. 6, no. 2. Reading, MA: Addison-Wesley, 1977.

[23] A. Bandura and N. J. Cliffs, Social foundations of thought and action: A social cognitive theory (pp. 376). Englewood . Englewoods Cliffs, NJ: Prentice-Hall, 1986.

[24] M. H. Fagan, S. Neill, and B. R. Wooldridge, "An empirical investigation into the relationship between computer self-efficacy, anxiety, experience, support and usage," J. Comput. Inf. Syst., vol. 44, no. 2, pp. 95-104, 2003, doi: 10.1080/08874417.2004.11647572.

[25] H. Jon-Chao, H. Chan-Jer, D. Chien-Yun, H. Ming-Yueh, L. Pei-Hsin, and C.-C. Lee, "Technology Anxiety and Implicit Learning Ability Affect Technology Leadership to Promote the use of Information Technology at Elementary Schools," in Procedia - Social and Behavioral Sciences, vol. 64, Amsterdam: Elsevier Science Bv, 2012, pp. 555-563.

[26] U. Sekaran and R. Bougie, Research Methods for Business: A Skill-Building Approach, 6th ed. Chicester: Wiley, 2013.

[27] P. D. Leedy and J. E. Ormrod, Practical Research: Planning and Design, 11th ed. Boston: Pearson, 2015.

[28] J. C. Westland, Structural equation models: From paths to networks, vol. 22. New York: Springer, 2019.

[29] N. Tabri and C. M. Elliott, Principles and Practice of Structural Equation Modeling, 3rd ed., vol. 1, no. 1. Guilford, 2012.

[30] C. M. Ringle Wende, Sven, and Becker, Jan-Michael, "SmartPLS Release: 3." SmartPLS GmbH, Boenningstedt, Germany , 2015, [Online]. Available: http://www.smartpls.com.

[31] W. Abdillah and H. Jogiyanto, Partial Least Square (PLS) Alternatif Structural Equation Modeling (SEM) dalam Penelitian Bisnis, vol. I, no. 1. Yogyakarta: Penerbit Andi, 2015.

[32] X. Roser Cussó-Calabuig; Xavier Carrera Farran; Bosch-Capblanch, "Effects of intensive use of computers in secondary school on gender differences in attitudes towards ICT: A systematic review," Educ. Inf. Technol., vol. 23, no. 5, pp. 2111-2139, 2018, doi: 10.1007/s10639-018-9706-6.

[33] Y. Zhao, S. Deng, and R. Zhou, "Understanding Mobile Library Apps Continuance Usage in China: A Theoretical Framework and Empirical Study," Int. J. Libr. Inf. Serv., 
INTENSIF, Vol.4 No.2 August 2020

ISSN: 2580-409X (Print) / 2549-6824 (Online)

DOI: https://doi.org/10.29407/intensif.v4i2.14455

vol. 65 , no. 3, pp. 161-173, 2015, doi: 10.1515/libri-2014-0148.

[34] M. Limayem and C. K. Cheung, "Predicting the continued use of Internet-based learning technologies: the role of habit.," Behav. Inf. Technol., vol. 30, no. 1, pp. 91-99, 2011, doi: 10.1080/0144929X.2010.490956.

[35] Y. Liu and T. Bakici, "Enterprise social media usage: The motives and the moderating role of public social media experience.," Comput. Hum. Behav., vol. 101, pp. 163-172, 2019, doi: 10.1016/j.chb.2019.07.029. 